\title{
Deep planktonic filter-feeders found in the aphotic zone with the Cyana submersible in the Ligurian Sea (NW Mediterranean)
}

\author{
Philippe Laval, Jean Claude Braconnot, Nadja Lins da Silva
}

Observatoire Océanologique, URA 716 du CNRS, Station zoologique, BP 28, F-06230 Villefranche-sur-Mer, France

\begin{abstract}
Dives made during spring 1988 in the Ligurian Sea with the Cyana submersible uncovered a deep layer of active salps Salpa fusiformis and large appendicularians (a new species of Oikopleura). These zooplanktonic organisms stayed at a depth of about $400 \mathrm{~m}$, and did not perform vertical migrations. There was a substantial amount of living micro- and nanoplankton, transported by the strong downwelling due to the Ligurian convergence, at the depth of the layer where the filterfeeders were. We believe that this circulation process occurs year-round and provides sufficient particulate matter to sustain midwater populations of salps and appendicularians.
\end{abstract}

\section{INTRODUCTION}

Deep fragile macroplanktonic organisms may in most cases be observed and sampled only with submersibles. Plankton nets destroy many ctenophores or such delicate structures as larvacean houses; long salp chains are broken and are not effectively collected by fine mesh nets.

In April 1986, dives were conducted with the submersible 'Cyana' in the Ligurian Sea during the MIGRAGEL I cruise (Laval et al. 1989) to observe fragile macroplankton that are poorly represented in net-collected samples. One of the main objectives was to study the development of a salp bloom, an event which regularly occurs in spring in this area (Braconnot 1971). Unfortunately, 1986 happened to be an exceptional year. There was no salp bloom. Instead, a deep population of large appendicularians (houses 4 to $5 \mathrm{~cm}$ in diameter) was observed for the first time in this area.

In May 1988, a second submersible cruise, MIGRAGEL II, was undertaken in the same area. This time, salps were present in large numbers, as well as the large appendicularians. These appendicularians cooccurred in the mesopelagic zone with a deep population of salps. This paper reports the distribution of both these filter-feeders and the specific composition of their trophic environment.

\section{METHODS}

Sampling. Eight submersible dives (Table 1; MG1 to MG8) were made in the area of the Ligurian Sea already sampled during MIGRAGEL I. A map showing these stations may be found in Gorsky et al. (1991). The Cyana was equipped with two 6.51 'detritus samplers' (Youngbluth 1984).

Distribution of macroplanktonic animals. Standing stocks were determined using the same method as for MIGRAGEL I (Laval et al. 1989). However, results are reported here in a semi-quantitative coded form more suitable for depicting population densities (see legend to Fig. 1). For each layer, the code corresponds to the maximum abundance observed. Small variations between observers, in illumination of the field of view, or in time spent in the layers are greatly smoothed with this coding. This depiction is nevertheless representative of the relative abundance of zooplankton that exhibit a high level of patchiness.

Average densities corresponding to each code were estimated as follows. The surface scanned by the observer from the porthole was measured before the MIGRAGEL II cruise by submerging the vessel in a test basin. At a mean observational distance of $1.5 \mathrm{~m}$, this surface was $4.6 \mathrm{~m}^{2}$; it had been estimated (with less precision) in a previous paper to be about $4 \mathrm{~m}^{2}$ (Laval \& Carré 1988). Because counting encompassed 
Table 1. Characteristics of dives in the Ligurian Sea

\begin{tabular}{|c|c|c|c|c|c|}
\hline Dive & $\begin{array}{c}\text { Date } \\
\text { (May 1988) }\end{array}$ & Location & $\begin{array}{l}\text { Nautical miles } \\
\text { from Cape Ferrat }\end{array}$ & $\begin{array}{l}\text { Start-End } \\
(\mathrm{UT}+2 \mathrm{~h})\end{array}$ & $\begin{array}{l}\text { Max. dive depth } \\
\text { (m) }\end{array}$ \\
\hline MG1 & 14 & $43^{\circ} 37.7^{\prime} \mathrm{N}, 7^{\circ} 26.6^{\prime} \mathrm{E}$ & 6 & $21: 41-02: 00$ & 615 \\
\hline MG2 & 15 & $43^{\circ} 35.6^{\prime} \mathrm{N}, 7^{\circ} 29.4^{\prime} \mathrm{E}$ & 8 & $21: 40-01: 53$ & 625 \\
\hline MG3 & 16 & $43^{\circ} 37.2^{\prime} \mathrm{N}, 7^{\circ} 26.6^{\prime} \mathrm{E}$ & 6 & $21: 11-01: 30$ & 625 \\
\hline MG4 & 17 & $43^{\circ} 35.6^{\prime} \mathrm{N}, 7^{\circ} 29.4^{\prime} \mathrm{E}$ & 8 & $14: 50-19: 22$ & 590 \\
\hline MG5 & 19 & $43^{\circ} 27.8^{\prime} \mathrm{N}, 7^{\circ} 46.8^{\prime} \mathrm{E}$ & 23 & $09: 33-14: 16$ & 692 \\
\hline MG6 & 20 & $43^{\circ} 32.8^{\prime} \mathrm{N}, 7^{\circ} 35.2^{\prime} \mathrm{E}$ & 13 & $10: 30-15: 10$ & 610 \\
\hline MG7 & 21 & $43^{\circ} 35.9^{\prime} \mathrm{N}, 7^{\circ} 28.8^{\prime} \mathrm{E}$ & 8 & $09: 48-14: 45$ & 970 \\
\hline MG8 & 22 & $43^{\circ} 36.0^{\prime} \mathrm{N}, 7^{\circ} 39.2^{\prime} \mathrm{E}$ & 8 & $09: 15-11: 25$ & 457 \\
\hline
\end{tabular}

animals situated from $0.5 \mathrm{~m}$ to about $4 \mathrm{~m}$ from the porthole, we took $5 \mathrm{~m}^{2}$ as a coarse estimate. For calculating densities, the water column was divided in layers $20 \mathrm{~m}$ thick. The volume scanned along a $20 \mathrm{~m}$ vertical path was thus roughly $100 \mathrm{~m}^{3}$. When many individuals were close together, we assumed a cubic arrangement (as was done in Laval et al. 1989). An inter-individual spacing of $1.5 \mathrm{~m}$ corresponds to about 300 individuals per $1000 \mathrm{~m}^{3}$.

Distribution of microplankton and nanoplankton. After the dives, a fraction of the water contained in the 'detritus samplers' was kept for counting; these samplers were usually closed with a large appendicularian inside, except for MG8, during which a large planktonic foraminifer was caught, and MG6, when only water from the appendicularian layer was taken.

One hydrological cast with Niskin bottles at 0,50 , $100,200,300,400,550$, and $600 \mathrm{~m}$ was also made from the research ship of the Station zoologique, RV 'Korotneff', at a station (Stn H) close to dive MG6, but 1 nautical mile away, for safety reasons.

Samples were preserved with Lugol's solution and counted after settling in a $100 \mathrm{ml}$ Utermöhl chamber. For phytoplankton, only pigmented cells were considered. Cells were also counted in samples from the 'detritus samplers' for all dives, and in surface samples for dives MG7 and MG8.

\section{RESULTS}

\section{Distribution of salps (Fig. 1)}

Two species were abundant in the upper layers: Ihlea punctata (Forsskål - usually but erroneously spelled Forskål; see Hureau \& Monod 1973, p. 322), and Salpa fusiformis Cuvier. The former occupied the first $100 \mathrm{~m}$, while the latter extended from 0 to 150 or $200 \mathrm{~m}$.

Below the upper layers occupied by salps, there was in almost all dives, between 150 and $250 \mathrm{~m}$, a layer almost devoid of conspicuous organisms, which the observers called the 'desert zone'. This layer was seen in many submersible campaigns in this area.

Below the desert zone, the submersible dives uncovered an unforeseen aspect of the Salpa fusiformis distribution. A population of this species was observed between 400 and $600 \mathrm{~m}$ during all dives except MG1 and MG5 (Fig. 1). Live oozooids (solitaries) and blastozooids (chains) were present and were rimming slowly, in the same way they normally filter water for feeding. Some blastozooids carried embryos, an indication that the population was healthy. This deep population did not reach high densities (as is apparent from the absence of Code 3 in Fig. 1), but was regularly present. Its abundance increased from the station at 6 nautical miles from Cape Ferrat to those at 8 and 13 miles; it was deeper at these offshore stations (500 to $550 \mathrm{~m}$ ). No deep $S$. fusiformis were observed at the 23-mile station, MG5, where the maximum dive depth was $692 \mathrm{~m}$.

\section{Distribution of Phronima sedentaria (Fig. 1)}

Results concerning the hyperiid amphipod Phronima sedentaria (Forssk.) are presented here together with those of the salps because, in the Ligurian Sea, this parasitoid crustacean depends on them for feeding and making its 'barrel' (Laval 1978, 1981). The consequences of this feature are discussed below.

For the deep layer, the distribution of Phronima sedentaria corresponded closely to that of the salps, with 2 notable exceptions. In dive MG1, no Salpa fusiformis were observed below $300 \mathrm{~m}$, while $P$. sedentaria was abundant between 340 and $520 \mathrm{~m}$ (there were also some $P$. sedentaria between 10 and $280 \mathrm{~m}$ ). In dive MG5, there were a few $P$. sedentaria individuals in the 420 to $440 \mathrm{~m}$ layer, but a continuous population, increasing in density with depth, was seen from 640 to $692 \mathrm{~m}$, the end-of-dive limit. 


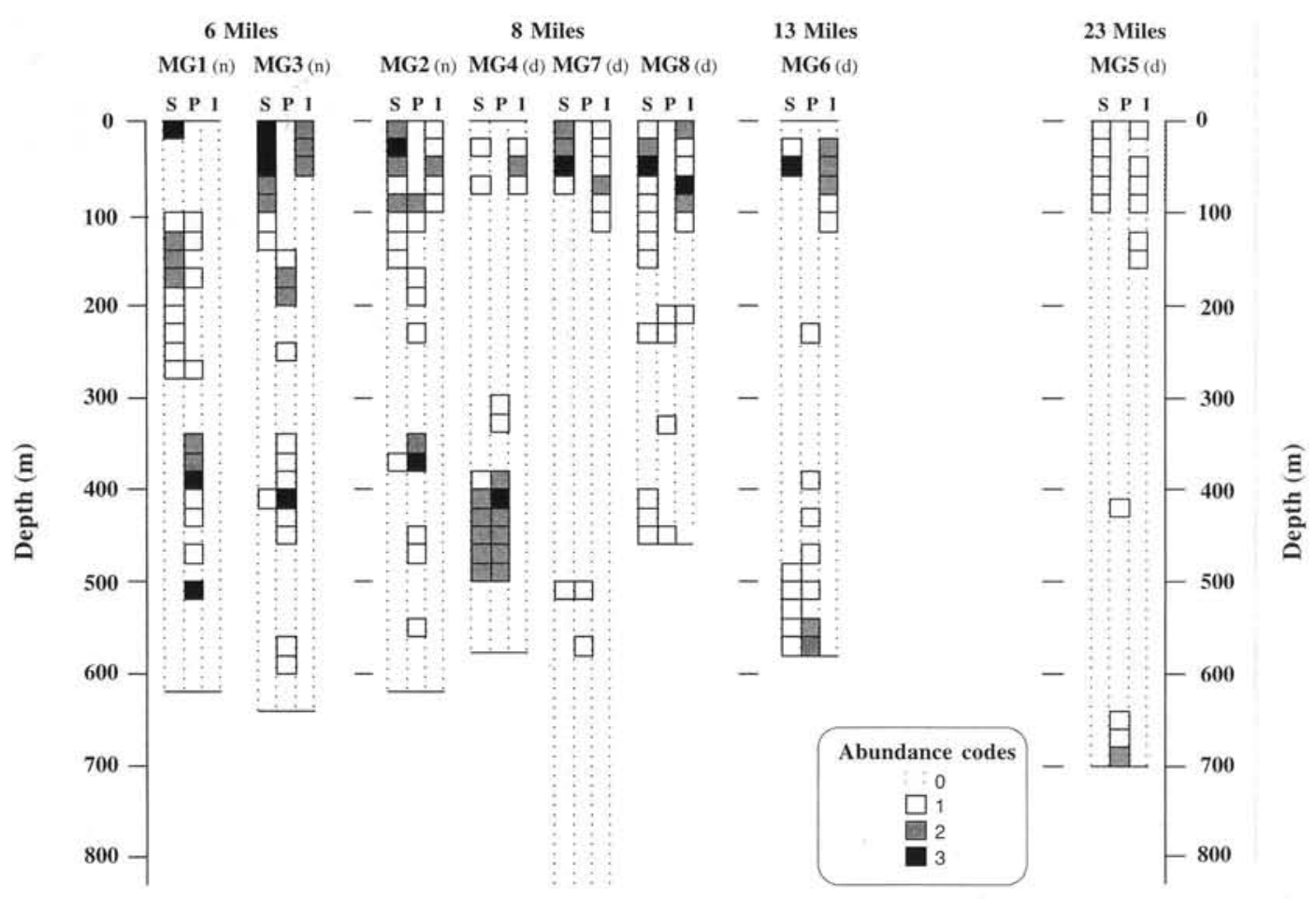

Fig. 1. Salpa fusiformis, Phronima sedentaria, Ihlea punctata. Depth distribution of 2 species of salps and an amphipod during the MIGRAGEL II cruise, at Stns MG1 to MG8. (d) or (n): day or night dive. S: S. fusiformis; P: P. sedentaria; I: I. punctata. For each 20 m layer, the abundance codes are as follows: (0) absence; (1) corresponds to 1-5 animals in the field of view; (2) and (3) correspond to $>5$ animals, with inter-individual distances $>1.5 \mathrm{~m}$ and $\leq 1.5 \mathrm{~m}$. Dive MG7 reached $970 \mathrm{~m}$. The horizontal spacing of the dives is not drawn to scale

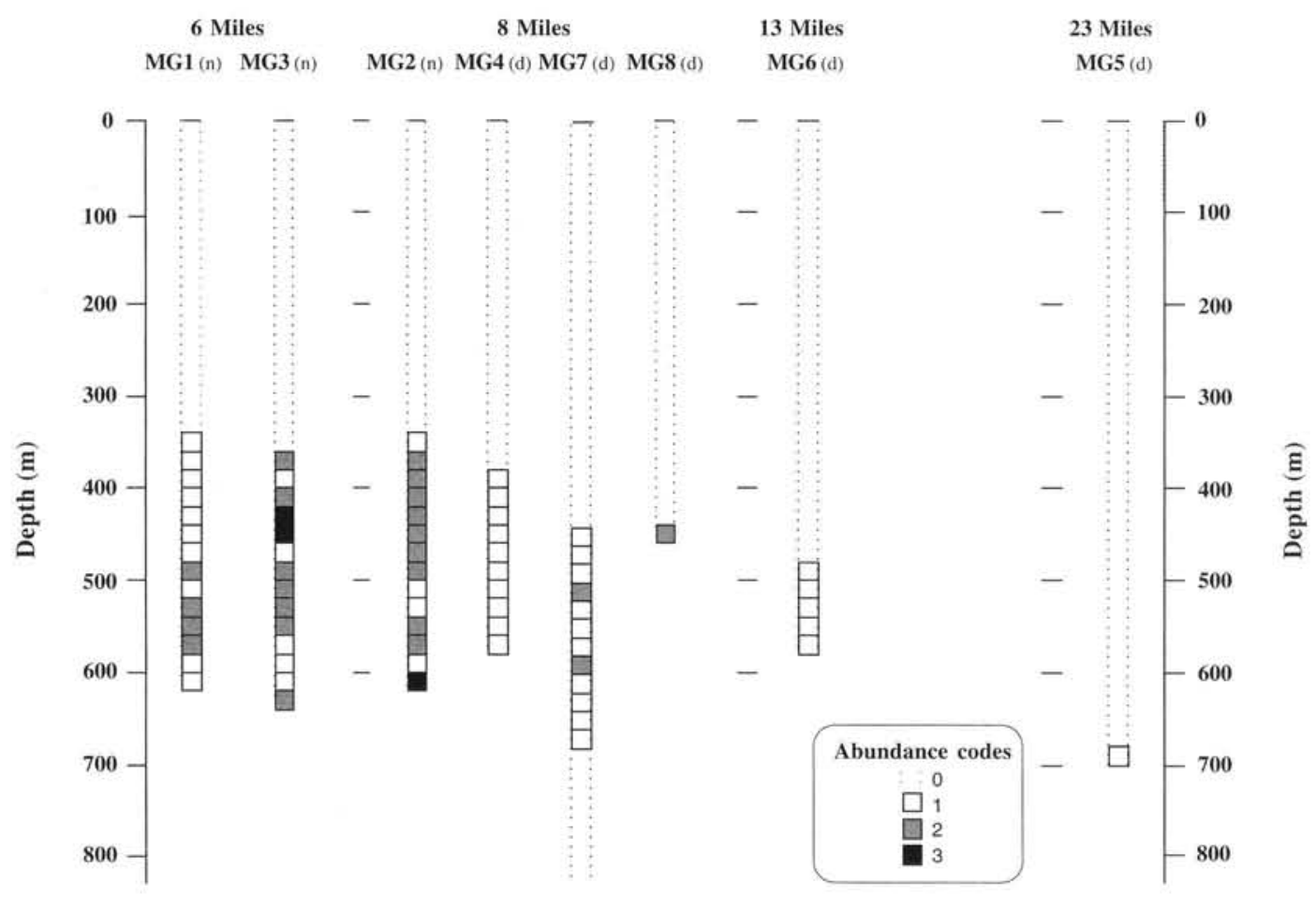

Fig. 2. Oikopleura sp. Depth distribution of a large new appendicularian species. Codes and abbreviations as in Fig. 1 


\section{Distribution of large appendicularians (Fig. 2)}

The deep population of a large species of Oikopleura found during MIGRAGEL I (Laval et al. 1989) occurred at the same place during MIGRAGEL II [according to R. Fenaux (pers. comm.) it is a new species, which will be described as $O$. villafrancae]. This species was always present in moderate numbers below $320 \mathrm{~m}$, down to $600 \mathrm{~m}$ and more. Its upper limit deepened as the distance from the coast increased, and it is apparent from Fig. 2 that the dive MG5 reached only the top of its depth range.

\section{Distribution of microplankton and nanoplankton}

The diatoms Leptocylindrus danicus $\mathrm{Cl}$. and Nitz-

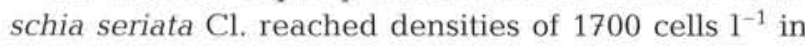
surface water at Stn $\mathrm{H}$. Other abundant species in the surface water were Rhizosolenia alata (Bright) and

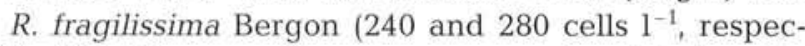
tively). These species were rare or absent below the surface.

The composition of micro- and nanoplankton populations at the depth of the deep filter-feeder's layer is given in Table 2. Five species were present at densities $\geq 100$ cells $1^{-1}$, some at depths $>500 \mathrm{~m}$.

\section{DISCUSSION}

\section{Presence of a deep population of Salpa fusiformis}

The salps Ihlea punctata and Salpa fusiformis are frequently seen in the upper layers of this area and in the Bay of Villefranche in spring. However, direct observation of numerous $S$. fusiformis below $400 \mathrm{~m}$, in the aphotic zone of the Ligurian Sea, was unexpected. To understand this, it is helpful to consider previous observations, which at the time were dismissed because of the uncertainty attached to the collecting devices, especially for deep operations.

Salpa fusiformis was present in vertical openingclosing plankton tows made in May 1963 in the same area, 10 and 15 nautical miles off Villefranche, in layers at $1000-600,1500-300$, and $300-100 \mathrm{~m}$ depth (Braconnot et al. 1965). Franqueville (1971) also caught this species in (non-closing) IKMT pelagic trawls between 300 and $800 \mathrm{~m}$, not far from this area. In the tropical Atlantic, Godeaux \& Goffinet (1968) found S. fusiformis below $300 \mathrm{~m}$ in 42 samples out of 91 .

Even in our MIGRAGEL I submersible dives (Laval et al. 1989), when there were no salps in the surface layers, we observed a few individuals (oozooids and blastozooids) of Salpa fusiformis between 150 and
$500 \mathrm{~m}$; they were not reported in that paper because of their scarcity. Retrospectively, these observations appear significant, because they showed the persistency of a sparse deep population even in the absence of a surface spring bloom.

\section{Do Salpa fusiformis undergo diel vertical migrations in the Ligurian Sea?}

By 'diel vertical migrations', we mean that the bulk of the population is found in the upper layers at night, and is found at much greater depths during the daytime. Long-range vertical migrations are known for the closely related species Salpa aspera (Wiebe et al. 1979). Our data do not show any clear evidence of such behavior for $S$. fusiformis. During the daytime dives (MG4 to MG8), as well as during the nighttime dives, $S$. fusiformis was present in significant numbers in the upper layers. Except in MG1, the deep population was also always present, both day and night (although in low numbers during the 2 nighttime dives, MG2 and MG3). Its absence at depth in MG1 was not accompanied by a corresponding absence of Phronima sedentaria (see below).

These underwater observations are consistent with results from several years of plankton net collections in the same area (Braconnot 1971, Braconnot et al. 1990), which show the presence of Salpa fusiformis, often in large numbers, in the upper layers during daytime. However, it should be noted that no systematic sampling has been conducted with an opening-closing net for the purpose of studying any possible vertical migration of this species in this area. There is no doubt that $S$. fusiformis occurs in abundance in the upper layers during daytime in the Ligurian Sea. This does not appear to be the case in the North Atlantic. Here Harbison \& Campenot (1979), using SCUBA, almost never found $S$. fusiformis (or $S$, aspera) in the upper layers during daytime.

Franqueville (1971) claimed that Salpa fusiformis undergoes diel vertical migration. This assertion has been repeated by all subsequent workers, but it is suggested only by the illustrations in Franqueville's paper: the data for daytime did not include the 100 to $0 \mathrm{~m}$ layer, while night hauls did, and the Isaacs-Kidd trawl used had no closing device, so that specimens plotted at depth may well have been caught all along the way up. Visually an upward migration seemed to take place at night, but this was not supported by the underlying data.

We are not saying here that Salpa fusiformis does not migrate vertically in the Ligurian Sea, only that the bulk of the population does not move up and down on a nycthemeral basis. This does not preclude that a few 
Table 2. Abundance (cells $~^{-1}$ ) of living microplankton and nanoplankton below $300 \mathrm{~m}$ during the MIGRAGEL II cruise. Values $\geq 100$ are underlined. H: hydrological station sampled from the RV 'Korotneff', 1 nautical mile from dive MG6, at the same time; Distance: distance from coast (nautical miles); Sampling devices: S, detritus sampler attached to the submersible; N, Niskin bottle; Depth: depth of sample (m)

\begin{tabular}{|c|c|c|c|c|c|c|c|c|c|c|c|c|}
\hline $\begin{array}{r}\text { Dive: } \\
\text { Distance: } \\
\text { Sampling device: } \\
\text { Depth: }\end{array}$ & $\begin{array}{l}\text { MG3 } \\
8 \\
\text { S } \\
450\end{array}$ & $\begin{array}{c}\text { MG4 } \\
8 \\
\text { S } \\
418\end{array}$ & $\begin{array}{c}\text { MG7 } \\
8 \\
\text { S } \\
490\end{array}$ & $\begin{array}{l}\text { MG7 } \\
8 \\
\text { S } \\
509\end{array}$ & $\begin{array}{l}\text { MG8 } \\
8 \\
\text { S } \\
450\end{array}$ & $\begin{array}{c}\mathrm{H} \\
12 \\
\mathrm{~N} \\
300\end{array}$ & $\begin{array}{c}\mathrm{H} \\
12 \\
\mathrm{~N} \\
400\end{array}$ & $\begin{array}{c}\mathrm{H} \\
12 \\
\mathrm{~N} \\
500\end{array}$ & $\begin{array}{c}\mathrm{H} \\
12 \\
\mathrm{~N} \\
600\end{array}$ & $\begin{array}{c}\text { MG6 } \\
13 \\
\text { S } \\
570\end{array}$ & $\begin{array}{l}\text { MG5 } \\
23 \\
\text { S } \\
300\end{array}$ & $\begin{array}{c}\text { MG5 } \\
23 \\
\text { S } \\
680\end{array}$ \\
\hline \multicolumn{13}{|l|}{ Diatoms } \\
\hline Amphora sp. & 20 & 10 & & & & & & & & & & \\
\hline Asterionella glacialis Castr. & & & & & 20 & & & & & & & \\
\hline $\begin{array}{l}\text { Asteromphalus sp. } \\
\text { Bacteriastrum delicatulum Cleve }\end{array}$ & & & & 10 & & 10 & & & & 10 & & \\
\hline Coscinodiscus sp. & $\underline{260}$ & & & & & & 10 & & 10 & & & 50 \\
\hline Coscinodiscus radiatus Ehr. & 20 & & & & & & & & & & & \\
\hline Ditylum brightwelli (West) Grunow & 20 & 10 & 10 & & & 20 & & 10 & 30 & 10 & & 20 \\
\hline Leptocylindrus danicus Cleve & & & & 10 & 10 & & & & & & & \\
\hline Nitzschia delicatissima Cleve & & & & & 20 & & & & & & & \\
\hline Nitzschia seriata Cleve & & & & & & & & & & & 160 & \\
\hline Nitzschia sp. & $\underline{420}$ & & & & & & 30 & & 20 & 170 & 10 & 10 \\
\hline Pleurosigma sp. & & & & & & 20 & & 20 & & & & \\
\hline Rhaphoneis sp. & 80 & & & & & & & & 10 & & & \\
\hline Rhizosolenia setigera Bright. & & & & & & & & & & & & 10 \\
\hline Rhizosolenia styliformis Bright. & & & & & & & & & & & 10 & \\
\hline Skeletonema costatum (Grev.) Cleve & & & & & & & & & & 40 & & \\
\hline $\begin{array}{l}\text { Thalassiosira eccentrica (Ehr.) Cleve } \\
\text { Thalassiosira sp. }\end{array}$ & $\frac{120}{20}$ & 110 & 10 & 70 & 110 & 100 & 170 & 220 & 40 & 280 & 190 & 111 \\
\hline Thalassionema nitzschioides Grunow & & & & & & & & & & & $\frac{10}{20}$ & \\
\hline Thalassiotrix frauenfeldi Grunow & & & & 20 & & & & & & & & \\
\hline Triceratium alternans Bailey & & & & & & & & & 20 & & & \\
\hline \multicolumn{13}{|l|}{ Dinoflagellates } \\
\hline Gymnodinium sp. & & & & & 10 & & & & & 30 & & \\
\hline Gyrodinium spirale (Bergh.) Kofoid \& S & wezy & & & 10 & & & & 60 & & & & \\
\hline \multicolumn{13}{|l|}{ Silicoflagellates } \\
\hline Dictyocha fibula Ehr. & & & & 10 & & 10 & 10 & & & 20 & & \\
\hline \multicolumn{13}{|l|}{ Tintinnids } \\
\hline Dadayella ganymedes (Entz Sr.) & & & & & & & & & & & 10 & \\
\hline Tintinnopsis nana Lohmann & & & & & & 10 & 10 & & 10 & & & \\
\hline \multicolumn{13}{|l|}{ Ciliates } \\
\hline Mesodinium rubrum Lohmann & & 10 & 30 & & & 40 & 50 & 10 & & & & 10 \\
\hline Total & 960 & 140 & 50 & 130 & 170 & 210 & 280 & 320 & 140 & 560 & 400 & 210 \\
\hline
\end{tabular}

individuals move vertically, essentially when the hydrological conditions become homogeneous at the end of winter.

\section{Phronima sedentaria as an aid in salp detection}

The close correlation noted between the depth distributions of Salpa fusiformis and Phronima sedentaria is not surprising, owing to the peculiar biology of phronimids. It was mentioned above that these amphipods live in tunicate 'barrels'. For $P$. sedentaria, these barrels come from salps (and also pyrosomes). The amphipod uses them to protect and rear their off- spring. Salps are sought for making barrels, and are part of the amphipod diet.

In the northwestern Mediterranean Sea, Phronima sedentaria is found in the upper layers at night, and below $200 \mathrm{~m}$ during daytime (Vu Do 1981). This was confirmed by our results: its upper limit was higher during the night dives (MG1 to MG3) than during the daytime dives (MG4 to MG8). It did not co-occur with Ihlea punctata. This is consistent with the fact that its barrel comes from the oozooid of Salpa fusiformis (Laval 1978). It may also be built from Pyrosoma atlanticum (Péron), but only one individual of this species was seen from Cyana during MIGRAGEL II (Stn MG1, at $108 \mathrm{~m}$ depth). 
The fact that hyperiid amphipods are attracted by the submersible lights is a common observation made from submersibles (own obs., and M. Youngbluth pers. comm.). Sometimes 'clouds' of amphipods such as Brachyscelus crusculum Spence Bate follow the descent of the submersible for over more than $100 \mathrm{~m}$; if the lights are switched off several minutes while the submersible goes down, the amphipods are 'lost' when the lights are switched on again, but they soon reappear in numbers. Amphipods such as Phronima sedentaria or Platyscelus ovoides (Claus) do not form very dense clouds, but they follow the submersible's descent, and their numbers increase when the descent pauses.

If we assume that (1) the distribution of salps is patchy, (2) the amphipod can detect the submersible lights from a great distance, and (3) Phronima sedentaria stays inside, or close to, patches of Salpa fusiformis, then the presence of a few P. sedentaria is an indication that a salp patch is present at some distance from the submersible. This explanation may account for the fact that no deep $S$. fusiformis were observed in dive MG1, while numerous $P$. sedentaria were attracted by the submersible lights (Fig. 1). Also, $S$. fusiformis was not observed below $650 \mathrm{~m}$ in MG5, but the presence of $P$. sedentaria may indicate that this was indeed the top of the salp layer.

The patchiness of the distribution of Salpa fusiformis is apparent in some studies (Braconnot 1971, Nival et al. 1990). This may be a consequence of its asexual reproduction (one solitary giving birth in a short time to several chains of aggregates). It is likely that the eyes of Phronima spp. are very sensitive, as well as capable of high resolution, as shown by histological studies (Ball 1977, Land 1981).

\section{What happens to Salpa fusiformis between the spring blooms?}

Our findings of a deep population of Salpa fusiformis may provide an explanation of the 'disappearance' of the species in the plankton collections from the upper layers between spring blooms (Andersen \& Nival 1986, Nival et al. 1990). These authors suggested that either (1) a small population of old salps takes refuge in deep layers, persisting there until the spring, or (2) they remain offshore, where they are not sampled, during winter. Regarding the first case, they observed that 'salps do not seem to have sufficient reserves to maintain a basal metabolism in these conditions'.

The complete salp life-cycle, including the solitary and the aggregate phase, lasts 20 to $25 \mathrm{~d}$ at $15^{\circ} \mathrm{C}$ (Braconnot et al. 1988). There is a rapid succession of generations during the spring bloom, and the salps spread over the entire Ligurian Basin. They disappear from the upper layers at the beginning of summer (Braconnot 1971).

As shown by Braconnot et al. (1988), a density of only 1 individual of Salpa fusiformis per $100 \mathrm{~m}^{3}$ is enough, in February, to produce a very dense population (1000 to 1500 ind. per $100 \mathrm{~m}^{3}$ ) 2 mo later. In February, the water column is homogeneous from the surface down to at least $600 \mathrm{~m}$. It is thus not hard to suppose that a few individuals may then swim from the deep layer to the upper layers, where they may take advantage of the highly favorable conditions for re-initiating the spring bloom.

\section{The deep filter-feeder layer}

Salps and large appendicularians co-occurred in the deep layer, with the same distributional pattern relative to the frontal zone (i.e. they were found deeper at the 23-mile station than in the more coastal station, the frontal zone itself being near the 13-mile station).

The presence of a healthy deep population of Salpa fusiformis raises some questions about their source of food. In the absence of light, there was still a significant number of living phytoplanktonic cells at the depth of the salp layer (Table 2 ). It is very likely that they were transported by the convergence induced by the frontal circulation (Sournia et al. 1990). Smayda (1971) recognized that downwelling may play an important role in the transport of phytoplankton to great depths. However, the amount of phytoplankton found in the salp layer does not seem sufficient to satisfy the food requirements of $S$. fusiformis, as calculated by Cetta et al. 1986. But $S$. fusiformis is also able to collect particles as small as $1 \mu \mathrm{m}$ (Morris et al. 1988, Bone et al. 1991), and this may account for the survival of the deep population between spring blooms.

For the large appendicularian species, measurements (Gorsky et al. 1991) showed that deep phytoplankton could provide less than $1 / 10$ of carbon requirements. To survive, the appendicularians must ingest substantial amounts of particulate organic matter. This point is fully discussed in Gorsky et al. (1991).

The above hypothesis concerning the presence of a small, perennial deep salp population requires that food be available over the entire year, not only during the spring bloom. Thus phytoplankton cannot be the only food source for these deep salps. Particulate matter originating from the Ligurian frontal zone, of which the micro- and nanoplankton found at depth is only a part, may provide a continuous flux sufficient to explain the persistence of the deep filter-feeder population. 
Acknowledgements. We thank I. Palazzoli for her help with video and photo manipulations during and after the cruise. G. Gorsky was a member of the scientific party, and also contributed with helpful discussions. M. J. Youngbluth conducted the MG7 dive; he kindly supplied the detritus samplers mounted on Cyana; he also helped to improve the manuscript. S. Dallot provided critical comments. The technical support of the Cyana pilots and crew was greatly appreciated. J. Goy (Muséum, Paris) informed us about the correct spelling of Forsskål. The cruise was supported by CNRS/INSU and IFREMER.

\section{LITERATURE CITED}

Andersen, V., Nival, P. (1986). A model of the population dynamics of salps in coastal waters of the Ligurian Sea. J. Plankton Res. 8: 1091-1110

Ball, E. (1977). Fine structure of the compound eyes of the midwater amphipod Phronima in relation to behavior and habitat. Tissue Cell 9: 521-536

Bone, Q., Braconnot, J. C., Ryan, K. P. (1991). On the pharyngeal feeding filter of the salp Pegea confoederata. Acta zool. (Stockholm) 72: 55-60

Braconnot, J. C., Carré, C., Goy, J., Sentz-Braconnot, E. (1965). Campagnes planctoniques en mer de Ligurie. Cah. océanogr. 17: 185-206

Braconnot, J. C. (1971). Contribution à l'étude biologique et écologique des Tuniciers pélagiques Salpides et Doliolides. I. Hydrologie et écologie des Salpides. Vie Milieu 22: 257-286

Braconnot, J. C., Choe, S. M., Nival, P. (1988). La croissance et le développement de Salpa fusiformis. Annls Inst. océanogr., Paris 64: 101-114

Braconnot, J. C., Étienne, M., Moitié, M. (1990). Distribution du Tunicier pélagique Salpa fusiformis Cuvier à Villefranche: 13 années d'observations. Rapp. P.-v. Réun. Commn int. Explor. scient. Mer Méditerr. 32: 225

Cetta, C. M., Madin, L. P., Kremer, P. (1986). Respiration and excretion by oceanic salps. Mar. Biol. 91: 529-537

Franqueville, C. (1971). Macroplancton profond (Invertébrés) de la Méditerranée nord-occidentale. Tethys 3: 11-56

Godeaux, J., Goffinet, G. (1968). Données sur la faune pélagique au large des côtes du Gabon, du Congo et de l'Angola. Tuniciers pélagiques. I. Salpidae. Annls Soc. r. Belg. 98: 49-86

Gorsky, G., Lins da Silva, N., Dallot, S., Laval, P., Braconnot, J. C., Prieur, L. (1991). Midwater tunicates: are they related to the permanent coastal front of the Ligurian Sea (NW Mediterranean)? Mar. Ecol. Prog. Ser. 74: 195-204

Harbison, G. R., Campenot, R. B. (1979). Effects of temper-

This article was submitted to the editor ature on the swimming of salps (Tunicata, Thaliacea): implications for vertical migration. Limnol. Oceanogr. 24: 1081-1091

Hureau, J.-C., Monod, T. (eds.) (1973). Catalogue des Poissons de l'Atlantique du Nord-Est et de la Méditerranée. CLOFNAM II, UNESCO, Paris

Land, M. F. (1981). Optics of the eyes of Phronima and other deep-sea amphipods. J. comp. Physiol. (Sect. A) 145: 209-226

Laval, P. (1978). The barrel of the pelagic amphipod Phronima sedentaria (Forsk.) (Crustacea: Hyperiidea). J. exp. mar. Biol. Ecol. 33: 187-211

Laval, P. (1981). Relations entre la femelle et le tonnelet chez Phronima sedentaria (Forsk.) (Amphipode Hypéride). Rapp. P.-v. Réun. Commn int. Explor. scient. Mer Méditerr. 27: 193-194

Laval, P., Braconnot, J. C., Carré, C., Goy, J., Morand, P., Mills, C. E. (1989). Small-scale distribution of macroplankton and micronecton in the Ligurian Sea (Mediterranean Sea) as observed from the manned submersible Cyana. J. Plankton Res. 11: 665-685

Laval, P., Carré, C. (1988). Comparaisons entre les observations faites depuis le submersible CYANA et les pêches au chalut pélagique pendant la campagne MIGRAGEL I en mer Ligure (Méditerranée nord-occidentale), Bull. Soc. r. Liège 4/5: 249-257

Morris, R. J., Bone, Q., Head, R., Braconnot, J. C., Nival, P. (1988). Role of salps in the flux of organic matter to the bottom of the Ligurian Sea. Mar. Biol. 97: 237-241

Nival, P., Brancourt, J. C., Oberdorff, T. (1990). Structure démographique d'une population de salpes en mer Ligure. Mar. Nature 3: 1-8

Smayda, T. J. (1971). Normal and accelerated sinking of phytoplankton in the sea. Mar. Geol. 11: 105-122

Sournia, A., Brylinski, J.-M., Dallot, S., Le Corre, P., Leveau, M., Prieur, L., Froget, C. (1990). Fronts hydrologiques au large des côtes françaises: les sites-ateliers du programme Frontal. Oceanol. Acta 13: 413-438

Vu Do, Q. (1981). Crustacés micronectoniques en Mer Ligure. Rapp. P.-v. Réun. Commn int. Explor. scient. Mer Méditerr. 27: 143-144

Wiebe, P. H., Madin, L. P., Haury, L. R., Harbison, G. R., Philbin, L. M. (1979). Diel vertical migration by Salpa aspera and its potential for large-scale particulate organic matter transport to the deep-sea. Mar. Biol. 53: $249-255$

Youngbluth, M. J. (1984). Water column ecology: in situ observations of marine zooplankton from a manned submersible. In: Flemming, N. C. (ed.) Divers, submersibles and marine science. Mem. Univ. Newfoundland, Occ. Pap. Biol. 9: 45-57

Manuscript first received: July 5, 1991

Revised version accepted: December 13, 1991 